\title{
Pemanfaatan Tandan Kosong Kelapa Sawit Sebagai Media Tanam Pembibitan Batang Bawah Karet dengan Metode Root Trainer
}

\section{(Palm Oil Empty Bunches Utilization as Planting Media of Rubber Rootstocks Nursery using Root Trainer Method)}

\author{
Atminingsih $^{1)^{*}}$, Junaidi $^{1)}$, Mardiana Wahyuni ${ }^{2)}$, Eka Bobby Febrianto ${ }^{2)}$ \\ ${ }^{1)}$ Balai Penelitian Sungei Putih, Pusat Penelitian Karet, Galang, Deli Serdang, Po. Box 1415, \\ Medan, 20001 dan $^{2)}$ Sekolah Tinggi Ilmu Pertanian Agrobisnis Perkebunan (STIPAP) Medan, Jl. \\ Williem Iskandar, Medan Estate, Deli Serdang, Sumatera Utara, 20226 \\ E-mail: atminingsih85@gmail.com
}

\begin{abstract}
Root trainer technology can be an alternative for rubber plant nursery that have ease in transportation and distribution. Organic materials which are lightweight, porous, and contain nutrients are considered suitable for root trainer growing media. This research was carried out at Sungei Putih Research Center Greenhouse, Deli Serdang from January - May 2019. The research was arranged based on a Randomized Block Design (RBD) with 4 media combination treatments namely: top soil $\left(P_{0}\right)$, empty bunches and manure $\left(P_{1}\right)$, empty bunches and rice husks (P2), and empty bunches and solid decanters (P3). The results showed that the planting media did not have a significant effect on plant growth including stem diameter, plant height, and number of leaves, as well as the percentage of successful grafting. The treatment of oil palm empty fruit bunches and solid decanter gave better growth than other organic materials. The availability of empty bunches and solid decanter in North Sumatra is relatively abundant so that it can support rubber nurseries throughout the year.
\end{abstract}

Keywords: fruit bunches, growth, Hevea brasiliensis, oil palm empty, root trainer

DOI: http://dx.doi.org/10.25181/jaip.v8i2.1620

Diterima: 4 Juni 2020 / Disetujui: 22 September 2020 / Diterbitkan: 17 Oktober 2020

\section{PENDAHULUAN}

Perbanyakan tanaman karet umumnya dilakukan dengan cara okulasi yang memerlukan batang bawah (rootstock) dan batang atas (scion). Pembibitan batang bawah dapat dilakukan dua tahap (double stages nursery) di lapangan sampai okulasi kemudian dipindah ke pembibitan polibeg, atau dapat langsung ditanam di polibeg (single stage nursery). Untuk mendapatkan bahan tanam polibeg dibutuhkan waktu cukup lama (8-12 bulan) sampai bibit siap tanam. Selain itu, ukuran polibeg yang besar menyebabkan kesulitan dalam transportasi dan distribusi di lapangan. Dalam perkembangannya, upaya perbaikan terus dilakukan salah satunya dengan menggunakan root trainer (Nabayi, et al, 2018; Sumesh et al, 2015; Cahyo et al., 2016; Ardika, 2017). Root trainer adalah metode pembibitan dalam wadah khusus yang ditujukan untuk mengotimalkan 
pertumbuhan akar. Ardika dan Herlinawati (2014) menyatakan bahwa akar lateral dengan sistem root trainer lebih banyak sehingga pertumbuhan di lapangan lebih baik. Keunggulan lainnya adalah kemudahan dalam pengiriman jarak jauh dan distribusi di lapangan karena volume lebih rendah dan bobotnya lebih ringan.

Di India, negara asal teknologi root trainer untuk pembibitan karet, metode ini telah diterapkan dalam skala komersil, namun di Indonesia masih tergolong baru dan belum diadopsi dalam skala luas. Beberapa uji coba telah dilakukan dengan hasil yang cukup memuaskan, namun penerapan teknologi ini masih memerlukan penyempurnaan terutama dalam hal ketersediaan media tanam dan pola budidaya di Indonesia. Pembibitan dengan root trainer memerlukan bahan tanam yang tepat agar pertumbuhan akar optimal (Cahyo et al., 2016). Dari penelitian-penelitian sebelumnya, media tanam seminimal mungkin menggunakan tanah dan digantikan dengan bahan organik atau sintetis yang mampu memberikan aerasi, menahan air, dan memiliki kandungan hara yang baik (Salisu et al., 2016). Nabayi et al. (2018) melaporkan bahwa media tanam organik memberikan pertumbuhan paling baik dibanding bahan-bahan lainnya. Bahan organik seperti pupuk kandang dan sekam padi telah dikenal secara luas sebagai media tanam yang baik untuk budidaya sayuran dan tanaman hias diyakini juga dapat digunakan untuk pembibitan karet.

Provinsi Sumatera Utara merupakan salah satu daerah penghasil kelapa sawit. Luas tanaman kelapa sawit menghasilkan di Sumatera Utara mencapai 1,5 juta ha dengan produksi mencapai 5,6 juta ton tandan buah segar (TBS) (Direktorat Jenderal Perkebunan, 2018). Pengolahan TBS menghasilkan limbah berupa tandan kosong (23\%), cangkang (6,5\%), wet decanter solid (lumpur) (4\%), serabut (fiber) (13\%), dan limbah cair sebanyak 50\%. Ketersediaan bahan organik dari limbah pengolahan kelapa sawit yang melimpah memberikan peluang pemanfaatan sebagai media tanam untuk tanaman perkebunan termasuk karet. Tandan kosong kelapa sawit sangat potensial digunakan sebagai media tanam root trainer karena memiliki kandungan hara makro dan mikro yang cukup tinggi antara lain: $\mathrm{C}(42,8 \%), \mathrm{K}_{2} \mathrm{O}(2,9 \%), \mathrm{N}(0,8 \%)$, $\mathrm{P}_{2} \mathrm{O}_{5}(0,22 \%), \mathrm{MgO}$ (0,30\%), $\mathrm{Cu}$ (23 ppm), dan $\mathrm{Zn}$ (51 ppm) (Haryanti, 2014).

Penggunaan tandan kosong dan decanter solid sudah banyak dilakukan sebagai media tanam (Gusta et al., 2015; Harahap et al., 2014; Maryani, 2018), namun penggunaan bahan-bahan tersebut untuk pembibitan bawah tanaman karet dengan metode root trainer belum pernah dilakukan. Penelitian ini bertujuan untuk mengetahui pengaruh penggunaan tandan kosong kelapa sawit yang dikombinasikan dengan bahan organik lainnya terhadap pertumbuhan batang bawah tanaman karet. Penelitian ini berguna dalam upaya menyempurnakan teknik pembibitan tanaman karet sistem root trainer. 


\section{METODE PENELITIAN}

Penelitian dilaksanakan di rumah kaca Balai Penelitian Sungei Putih, Deli Serdang, Sumatera Utara pada bulan Januari - Mei 2019. Dalam penelitian ini digunakan dua jenis wadah media tanam yaitu root trainer dan polibeg. Root trainer yang digunakan berbentuk silindris berbahan polipropilen (Gambar 1), diameter atas 6,0 - 7,5 cm sedangkan bagian bawah 1,5 - 2,0 $\mathrm{cm}$, panjang $30 \mathrm{~cm}$ dengan kapasitas tampung $800 \mathrm{cc}$ dan dilengkapi lubang drainase dan alur vertikal di bagian dalam, sedangkan polibeg yang digunakan untuk tanaman pembanding berukuran $12 \times 25 \mathrm{~cm}$.

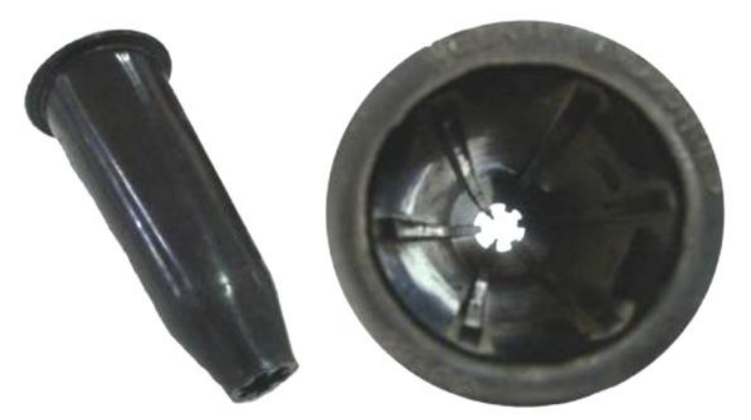

Gambar 1. Root trainer untuk pembibitan karet

Perlakuan media tanam yang diujicobakan dalam penelitian ini adalah kombinasi campuran tandan kosong kelapa sawit dengan salah satu bahan organik lain yaitu decanter solid, pupuk kandang, dan sekam padi (Tabel 1). Pencampuran media dilakukan dengan perbandingan volume 1:1. Sebagai pembanding digunakan media tanah (top soil) dalam polibeg.

Tabel 1. Kombinasi media tanaman yang digunaakan dalam penelitian

\begin{tabular}{ccc}
\hline Perlakuan & Komposisi media (v:v) & Wadah \\
\hline $\mathrm{P}_{0}$ & Top soil & Polibeg \\
$\mathrm{P}_{1}$ & Tandan kosong : pupuk kandang & Root trainer \\
$\mathrm{P}_{2}$ & Tandan kosong : sekam padi & Root trainer \\
$\mathrm{P}_{3}$ & Tandan kosong : decanter solid & Root trainer \\
\hline
\end{tabular}

Penelitian disusun berdasarkan Rancangan Acak Kelompok (RAK), masing-masing perlakuan menggunakan 10 tanaman dengan pengulangan sebanyak 3 kali. Batang bawah yang digunakan berasal dari biji klon PB 260 berumur 15 tahun. Biji disemaikan dalam media pasir selama 21 hari kemudian kecambah (stadia jarum) dipindahkan ke dalam root trainer dan polybag yang telah diisi media tanam sesuai perlakuan, Selama penelitian, kegiatan pemeliharaan meliputi pengendalian gulma dan penyiraman dilakukan sesuai standar pembibitan karet dalam polibeg atau disesuaikan dengan volume media tanam dalam root trainer. 
Pengamatan setiap dua minggu dilakukan terhadap peubah pertumbuhan tanaman, meliputi diameter batang, tinggi tanaman, dan jumlah daun sampai 18 minggu setelah tanam (mst). Pelaksanaan okulasi dilakukan pada umur batang bawah 5 bulan. Keberhasilan okulasi diamati pada 21 hari setelah okulasi. Persentase keberhasilan okulasi adalah perbandingan jumlah okulasi berhasil dengan jumlah total tanaman diokulasi. Analysis of variance (ANOVA) dilakukan untuk masing-masing faktor pertumbuhan yang diamati menggunakan $R$ Statistic Software version 3.6.3 ( $R$ Development Core Team) dalam $R$ Studio Interface version 1.1.383 (R Studio Inc.). Estimated Marginal Means diperoleh dengan menggunakan fungsi emmeans dan dibandingkan menggunakan Tukey method pada $\alpha=0,05$.

\section{HASIL DAN PEMBAHASAN}

\section{Diameter Batang}

Diameter batang merupakan parameter utama dalam pembibitan yang menentukan cepat lambatnya batang bawah dapat diokulasi. Dalam penelitian ini, kombinasi media tanam tidak berpengaruh secara signifikan terhadap diameter batang (Gambar 2a). Pada 18 mst diameter tertinggi dicapai pada perlakuan $\mathrm{P}_{3}$ yaitu $5,24 \pm 0,68 \mathrm{~mm}$ dan diameter terendah terdapat pada perlakuan $\mathrm{P}_{2}$ sebesar 4,76 $\pm 0,35 \mathrm{~mm}$. Sedangkan perlakuan kontrol $\left(\mathrm{P}_{0}\right)$ mencapai 5,18 $\pm 0,57 \mathrm{~mm}$ dan perlakuan $\mathrm{P}_{1}$ sebesar 4,99 $\pm 0,18 \mathrm{~mm}$. Laju pertambahan diameter merupakan rata-rata pertambahan yang diperoleh dari pengamatan peubah diameter setiap dua minggu sekali. Hasil pengamatan menunjukkan bahwa $P_{0}$ memiliki laju pertumbuhan tertinggi yaitu $0,16 \pm 0,03$ $\mathrm{mm} /$ minggu dan terendah pada $\mathrm{P}_{2}$ sebesar 0,14 $\pm 0,03 \mathrm{~mm} / \mathrm{minggu}$ (Gambar 2b). Hasil penelitian ini sejalan dengan penelitiaan yang dilakukan Ardika (2017) dan Cahyo (2016) yang menunjukkan bahwa penggunaan beberapa bahan organik seperti sabut kelapa (peat), sekam padi, serbuk gergaji, kompos, dan tanah gambut tidak memberikan pengaruh nyata terhadap peubah pertumbuhan termasuk diameter batang pada pembibitan tanaman karet menggunakan root trainer. Penelitian lainnya oleh Yustisia (2017) menunjukkan bahwa komposisi media juga tidak memiliki pengaruh yang nyata terhadap diameter pada pembibitan di polibeg. 

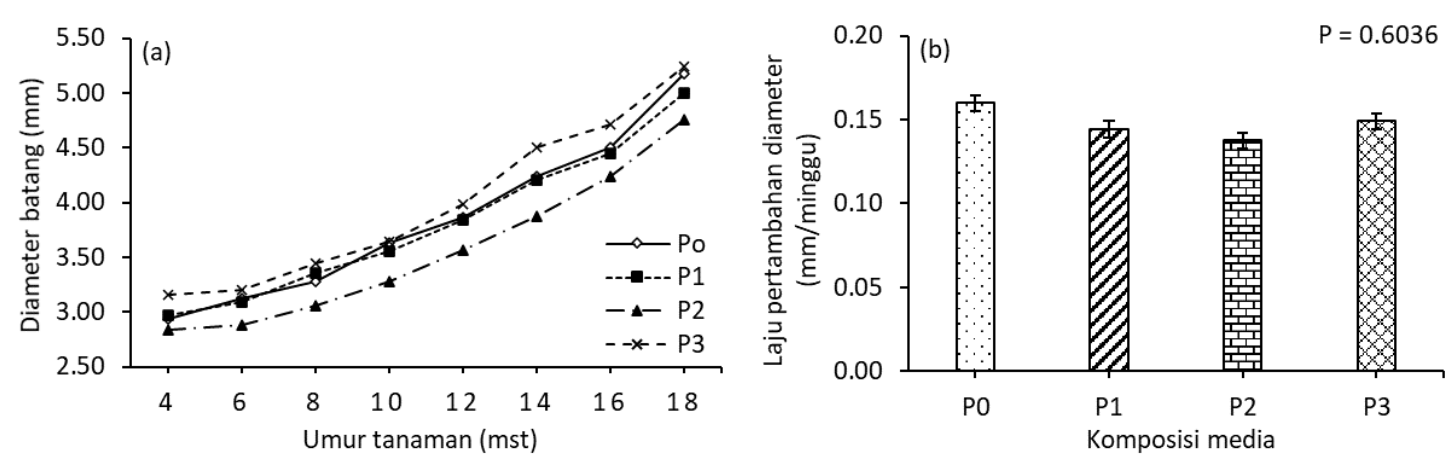

Gambar 2. Diameter batang masing-masing perlakuan selama pengamatan (a) dan laju pertambahan diameter batang berdasarkan komposisi media tanam (b); Error bar menunjukkan standar deviasi hb

Namun demikian, dibandingkan kombinasi media tanam organik lainnya, perlakuan kombinasi tandan kosong dan decanter solid $\left(\mathrm{P}_{3}\right)$ menunjukkan pertambahan diameter batang yang lebih tinggi dibanding sekam padi dan pupuk kandang meskipun masih lebih rendah dibandingkan kontrol. Perlakuan $\mathrm{P}_{3}$ memiliki rata-rata diamater batang paling tinggi pada setiap periode pengamatan. Hal ini menunjukkan kemungkinan variasi genetik kecambah yang ditanam di awal penelitian. Hasil penelitian ini menunjukkan bahwa penggunaan tandan kosong kelapa sawit sangat potensial digunakan untuk pembibitan karet jika dicampur dengan decanter solid. Hal ini sejalan dengan beberapa penelitian sebelumnya yang menunjukkan bahwa bahwa decanter solid mempunyai prospek untuk digunakan dalam pembibitan tanaman karet. Silitonga (2016) melaporkan bahwa bahwa decanter solid memberikan hasil terbaik dibandingkan limbah kelapa sawit lainya terhadap parameter pertumbuhan pembibitan tanaman karet. Lebih lanjut, penelitian Harahap (2018) menunjukkan bahwa decanter solid sebagai pencampur tanah bekas tambang batu bara pada pembibitan polibeg tanaman karet memberikan pengaruh nyata terhadap diameter batang.

\section{Tinggi Tanaman}

Hasil analisis menunjukkan bahwa komposisi media tidak nyata mempengaruhi tinggi tanaman. Hasil pengamatan menunjukkan $\mathrm{P}_{2}$ memiliki tinggi tanaman paling rendah dari awal pengamatan, sedangkan $\mathrm{P}_{0}, \mathrm{P}_{1}$, dan $\mathrm{P}_{3}$ memiliki tinggi yang cenderung sama. Tinggi tanaman bertambah secara linier sampai 15 mst, sedangkan berkurangnya nilai tinggi pada 16 mst disebabkan sebagian tanaman mati sehingga mempengaruhi nilai rata-rata (Gambar 3a). Pengamatan pada 18 mst menunjukkan nilai tertinggi dicapai oleh perlakuan $\mathrm{P}_{0}$ yaitu 80,17 $\pm 4,62$ cm, sedangkan nilai $\mathrm{P}_{1}, \mathrm{P}_{2}$, dan $\mathrm{P}_{3}$ berturut-turut adalah 73,59 $\pm 4,27 \mathrm{~cm} ; 72,48 \pm 3,13 \mathrm{~cm}$; dan $72,83 \pm 14,14 \mathrm{~cm}$. Berdasarkan pengamatan tinggi tanaman tiap dua minggu sekali, laju pertambahan tertinggi terdapat pada perlakuan kontrol yaitu 3,14 $\pm 0,35 \mathrm{~cm} /$ minggu, sedangkan ketiga perlakuan lainnya memiliki nilai yang cenderung sama yaitu 2,65 $\pm 0,32 \mathrm{~cm} / \operatorname{minggu}\left(\mathrm{P}_{1}\right)$; $3,02 \pm 0,28 \mathrm{~cm} \cdot \operatorname{minggu}^{-1}\left(\mathrm{P}_{2}\right)$, dan 2,75 $\pm 0,80 \mathrm{~cm} / \operatorname{minggu}\left(\mathrm{P}_{3}\right)($ Gambar $3 \mathrm{~b})$. 

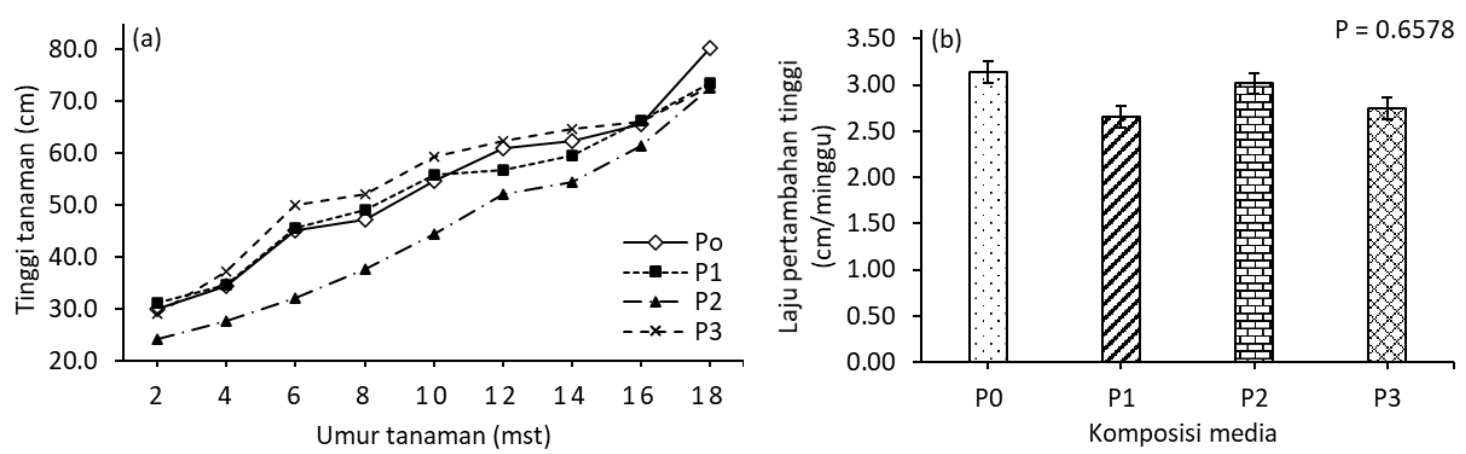

Gambar 3. Tinggi tanaman masing-masing perlakuan selama penelitian (a) dan laju pertambahan tinggi tanaman (b). Error bar menunjukkan standar deviasi

Komposisi media tanam dan asupan hara mendorong pertumbuhan bibit tanaman karet. Namun demikian, tinggi tanaman tidak hanya dipengaruhi faktor media tanam dan unsur hara. Pertumbuhan tanaman karet dipengaruhi oleh jenis klon dan agroekosistem (Acmad, 2016). Tetuko (2015) melaporkan bahwa hormon pertumbuhan juga berpengaruh nyata terhadap tinggi tanaman karet dari biji, perlakuan giberelin 200 ppm dan auksin 100 ppm menunjukkan pertumbuhan paling baik. Admojo et al. (2013) menyatakan bahwa tinggi internode batang tanaman karet juga sangat dipengaruhi oleh juvenilitas tanaman.

\section{Jumlah Daun}

Tanaman karet mempunyai morfologi daun majemuk (trifolia) dengan tangkai panjang, primodia daun tumbuh di ujung internode batang bisanya disebut payung daun. Daun yang berada dalam satu payung mempunyai umur yang sama, umumnya payung daun bertambah setiap bulan. Pertumbuhan daun tanaman karet berlangsung secara periodik, pada kondisi daun tua akan terjadi dormansi pucuk beberapa minggu sebelum muncul internode beserta daun baru.

Gambar 4a menunjukkan jumlah daun dari minggu ke 2 hingga ke 18. Secara umum pada semua kombinasi media tiap 4 minggu terjadi kenaikan jumlah daun seiring dengan penambahan payung daun. Hasil pengamatan menunjukkan jumlah daun mulai mengalami perbedaan dari payung kedua pada pengamatan 6 MST. Perlakuan $\mathrm{P}_{3}$ menunjukkan jumlah tertinggi dibandingkan dengan perlakuan lainnya. Rata-rata jumlah daun pada 18 MST perlakuan $\mathrm{P}_{3}$ mempunyai nilai tertinggi yaitu 11,33 $\pm 3,1$ daun, sedangkan terendah pada perlakuan $\mathrm{P}_{2}$ dengan 9,67 \pm 1,2 daun. Berdasarkan hasil pengamatan jumlah daun yang dilakukan setiap dua minggu, laju pertambahan jumlah daun tertinggi terdapat pada perlakuan $\mathrm{P}_{0}$ yaitu 0,56 daun/minggu (Gambar $4 \mathrm{~b}$ ). Secara statistik, laju Hasil penelitian ini menunjukkan bahwa pertambahan jumlah daun tidak dipengaruhi oleh komposisi media tanam. Penelitian yang dilakukan oleh Sitompul (2015) menyimpulkan bahwa media tanam dengan pemberian limbah cair pabrik kelapa sawit (LCPKS) tidak berpengaruh terhadap pertambahan jumlah daun pada bibit stump mini tanaman karet. 

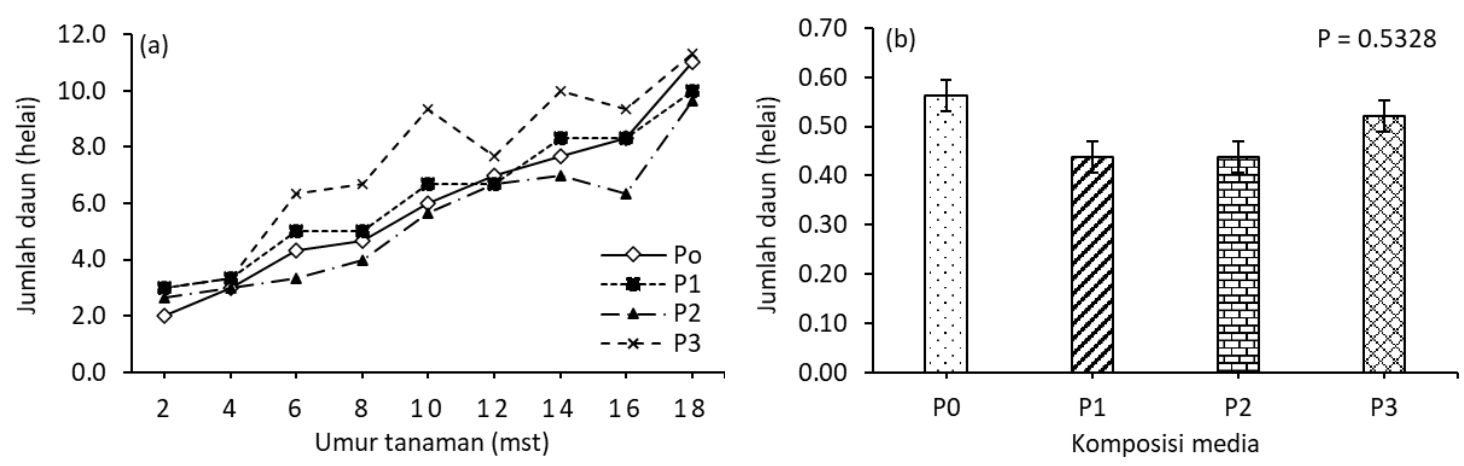

Gambar 4. Perkembangan jumlah daun pada setiap perlakuan selama penelitian (a) dan jumlah daun masing-masing perlakuan pada 18 MST (b); Error bar menunjukkan standar deviasi

\section{Persentase Keberhasilan Okulasi}

Okulasi adalah kegiatan penempelan mata tunas (entres) pada jendela okulasi batang bawah karet. Proses okulasi harus mempertimbangkan umur batang bawah yang digunakan. Penggunaan root trainer salah satunnya ditujukan untuk mempercepat proses pembibitan karet sehingga teknik okulasi yang dianjurkan adalah okulasi hijau (umur batang bawah 5 - 7 bulan) atau okulasi dini (umur batang bawah 2 - 4 bulan). Okulasi yang dilakukan pada penelitian ini menggunakan teknik okulasi dini dengan entres jenis mata sisik.

Berdasarkan hasil pengamatan setelah 21 hari okulasi, diperoleh persentase keberhasilan okulasi tertinggi pada perlakuan $\mathrm{P}_{2}$ yaitu $67 \%$ dan terendah pada perlakuan $\mathrm{P}_{1}$ dengan tingkat keberhasilan 50\%. Sedangkan perlakuan $\mathrm{P}_{0}$ dan $\mathrm{P}_{3}$ masing-masing sebesar $65 \%$ dan $62 \%$ (Gambar 5). Hasil penelitian ini menunjukkan bahwa media tanam tidak mempengaruhi tingkat keberhasilan okulasi. Hal ini disebabkan keberhasilan okulasi dipengaruhi oleh banyak faktor antara lain umur batang bawah (Heryana et al., 2014), waktu pelaksanaan okulasi (Pudjiono dan Adinugraha, 2013), dan jenis mata entres (Udayakumara dan Seneviratne, 2005; Junaidi et al., 2014). Keberhasilan okulasi juga dipengaruhi aktivitas kambium sebagaimana dilaporkan oleh Sariningtias et al. (2014) yang menyatakan bahwa keberhasilan okulasi tinggi jika dilakukan pada periode sel kambium aktif membelah.

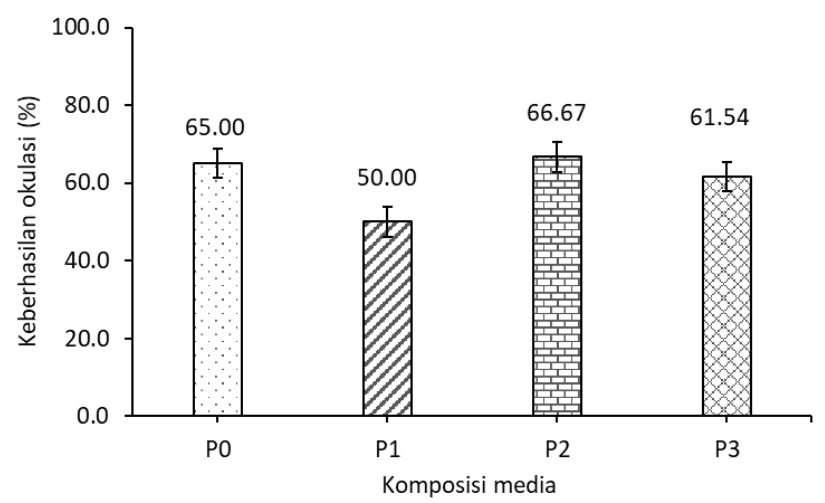

Gambar 5. Persentase keberhasilan okulasi pada masing-masing perlakuan 
Secara umum, pertumbuhan tanaman dengan media top soil lebih baik dibanding dengan bahan organik. Di antara kombinasi bahan organik yang diujicobakan, perlakuan tandan kosong kelapa sawit dan decanter solid cukup potensial dikembangkan sebagai media pembibitan karet dengan metode root trainer. Hal ini dengan pertimbangan laju pertambahan diameter batang dan persentase keberhasilan okulasi yang baik. Laju pertambahan diameter batang merupakan parameter penting yang menentukan umur tanaman dapat diokulasi, sedangkan persentase keberhasilan okulasi menentukan jumlah bibit yang dapat dihasilkan. Adapun paramater tinggi tanaman dan jumlah daun berguna sebagai indikator pertumbuhan tanaman, sebulan setelah okulasi tanaman akan dipotong (diserong) di atas jendela okulasi untuk mendorong pertumbuhan tunas dari mata entres sehingga tinggi tanaman dan jumlah daun tidak menjadi pertimbangan utama. Di Sumatera Utara, tandan kosong dan decanter solid relatif melimpah sepanjang tahun di pabrikpabrik pengolahan kelapa sawit sehingga dalam hal ketersediaan tidak menjadi masalah

\section{KESIMPULAN DAN SARAN}

\section{Kesimpulan}

Komposisi media tanam yang diujicobakan dalam penelitian ini tidak berpengaruh signifikan terhadap pertumbuhan tanaman. Namun demikian, tandan kosong kelapa sawit berpotensi digunakan sebagai media tanam pembibitan batang bawah karet dengan metode root trainer. Berdasarkan hasil pengamatan terhadap peubah laju pertambahan diameter batang dan keberhasilan okulasi, komposisi media tandan kosong dan decanter solid $\left(\mathrm{P}_{3}\right)$ lebih baik jika dibandingkan dengan pupuk kandang atau sekam padi.

\section{Saran}

Penelitian lebih lanjut diperlukan terutama dalam hal manajemen hara guna meningkatkan pertumbuhan melebihi pertumbuhan pada media tanah (pembanding).

\section{UCAPAN TERIMA KASIH}

Penelitian ini didanai oleh kerjasama penelitian antara Balai Penelitian Sungei Putih, Pusat Penelitian Karet dan Lembaga Penelitian dan Pengabdian Masyarakat (LPPM), Sekolah Tinggi Ilmu Pertanian Agribisnis Perkebunan (STIPAP) Medan tahun 2018/2019. Penulis menyampaikan terima kasih kepada kedua lembaga tersebut atas dukungan selama kegiatan penelitian berlangsung.

\section{DAFTAR PUSTAKA}

Admojo, L., Prasetyo, N. E., Afifah, E., \& Hadi, H. (2013). Pengaruh juvenilitas entres terhadap karakter tunas bibit okulasi dini tanaman karet. Jurnal Penelitian Karet, 31(1), 13-19. 
Ardika, R., \& Herlinawati, E. (2014). Alternatif penyediaan bahan tanam karet dengan sistem root trainer. Warta Perkaretan, 33(2), 73-78.

Ardika, R., Sanchez, P. B., Badayos, R. B., \& Cruz, P. C. S. (2017). Growth of PB 260 clone (Hevea brasiliensis (Willd. ex A. Juss.) Muell-Arg.) in different potting media and fertilization scheme. AGRIVITA, Journal of Agricultural Science, 39(2), 182-191.

Cahyo, A. N., Saputra, J., \& Stevanus, C. T. (2016). Penggunaan root trainer untuk meningkatkan pertumbuhan bibit karet. Jurnal Penelitian dan Pengembangan Pertanian, 35(1), 17-24.

Direktorat Jenderal Perkebunan. (2018). Statistik Perkebunan Indonesia: Kelapa Sawit 2017 2019. Direktorat Jenderal Perkebunan, Kementerian Pertanian. Jakarta: 81 pp.

Gusta, A. R., Kusumastuti, A., \& Parapasan, Y. (2015). Pemanfaatan kompos kiambang dan sabut kelapa sawit sebagai media tanam alternatif pada prenursery kelapa sawit (Elaeis guineensis Jacq.). Jurnal Penelitian Pertanian Terapan, 15(2), 151-155.

Harahap, R.A., Suherman, C., \& Rosniawaty, S. (2014). Pemanfaatan fungi mikoriza arbuskula pada media campuran subsoil dan kompos kulit pisang terhadap pertumbuhan kelapa sawit (Elaeis guineensis Jacq.) Varietas PPKS 540 di pembibitan awal. Agric. Sci. J., 1(4), 244-253.

Haryanti, A., Norsamsi, N., Sholiha, P. S. F., \& Putri, N. P. (2014). Studi pemanfaatan limbah padat kelapa sawit. Konversi, 3(2), 57-66.

Heryana, N., Saefudin, S., \& Sobari, I. (2014). Pengaruh umur batang bawah terhadap persentase keberhasilan okulasi hijau pada tiga klon karet (Hevea brasiliensis Muell Agr.). Jurnal Tanaman Industri dan Penyegar, 1(2), 95-100. https://doi.org/10.21082/jtidp.v1n2.2014.p95100.

Junaidi, Atminingsih, \& Siagian, N. (2014). Pengaruh jenis mata entres dan klon terhadap keberhasilan okulasi dan pertumbuhan tunas pada okulasi hijau di polibeg. Jurnal Penelitian Karet, 32(1), 21-30. https://doi.org/10.22302/jpk.v32i1.146.

Maryani, A.T. (2018). Efek pemberian decanter solid terhadap pertumbuhan bibit kelapa sawit (Elaeis guineensis Jacq.) dengan media tanah bekas lahan tambang batu bara di pembibitan

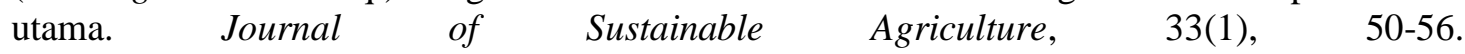
http://dx.doi.org/10.20961/carakatani.v33i1.19310.

Nabayi, A., Teh, C. B. S., Husni, M. H. A., \& Sulaiman, Z. (2018). Plant growth, nutrient content and water use of rubber (Hevea brasiliensis) seedlings grown using root trainers and different irrigation systems. Pertanika Journal of Tropical Agricultural Science, 41(1), 251-270.

Pudjiono, S., \& Adinugraha, H. A. (2013). Pengaruh klon dan waktu okulasi terhadap pertumbuhan dan persentase hidup okulasi jati (Tectona grandis). Wana Benih, 14(3), 103-108.

Rinaldi, R. (2018). Respons pertumbuhan bibit karet (Hevea brasiliensis Muell. Arg) satu payung klon PB 260 terhadap pemberian decanter solid pada media tanah bekas tambang batu bara di polybag. Jurnal Agroecotania: Publikasi Nasional Ilmu Budidaya Pertanian, 1(1), 33-42.

Salisu, M.A., Daud, W.N., Halim, R.A., Sulaiman, Z. (2016). Effect of soilless media on growth and some physiological traits of rubber (Hevea brasiliensis) seedlings. International Journal of Agriculture, Forestry and Plantation 3, 95 - 100. 
Sariningtias, N. W., Poerwanto, R., \& Gunawan, E. (2014). Penggunaan Benzil Amino Purin (BAP) pada okulasi jeruk keprok (Citrus reticulata). Jurnal Hortukultura Indonesia, 5(3), $158-167$.

Silitonga, B. (2016). Pertumbuhan Stump Mata Tidur Karet (Hevea brassiliensis Muell Arg) dengan Memanfaatkan Limbah Kelapa Sawit Sebagai Media Tanam. Undergraduate thesis, Universitas Sumatera Utara.

Sitompul, H.A., Husna Yetti, Arnis En Yulia.2015. Pemberian limbah cair pabrik kelapa sawit terhadap pertumbuhan bibit karet (Hevea Brasiliensis) Stum Mini. JOM Faperta, 2(1).

Tetuka, K. A., Parman, S., \& Izzati, M. (2015). Pengaruh Kombinasi Hormon Tumbuh Giberelin dan Auksin terhadap Perkecambahan Biji dan Pertumbuhan Tanaman Karet (Hevea brasiliensis Mull. Arg.). Jurnal Akademika Biologi, 4(1), 61-72.

Yustisia, D. (2017). Tingkat keberhasilan okulasi pada berbagai klon dan komposisi media tanam terhadap pertumbuhan tanaman karet (Hevea brasilliensis Muell Arg.). Agrominansia, 2(2), 110-118. 